documentation and presents a beautiful and rare collection. (Mark Nuttall, Scott Polar Research Institute, University of Cambridge, Lensfield Road, Cambridge CB2 IER UK.)

\section{THE SOUTH AMERICAN WAY}

STRATEGY IN THE SOUTHERN OCEANS. A SOUTH AMERICAN VIEW. Virginia GambaStonehouse. 1989. London, Pinter Publications (Studies in Contemporary Maritime Policy and Stategy). $155 \mathrm{p}$, maps, hard cover. ISBN 0-86187-017-4. £32.50.

Virginia Gamba-Stonehouse, an Argentinian, read Latin American Studies and Strategic Studies in the UK, taught Military Strategy to the Argentine War Schools and Joint Chiefs of Staff 1984-87, and has been a visiting professor in the USA and at King's College London. Examining strategies of South American countries in relation to each other and to Antarctica, she stresses their own interests in the south, which are neither widely known nor generally understood outside the sub-continent.

Implications of two important maritime issues are analyzed; Bolivian efforts to obtain an outlet to the Pacific Ocean, and the long-lasting dispute over the South Atlantic islands (including the Falklands/Malvinas Islands) and Antarctica. The latter is an important factor in Argentinian-Brazilian relationships. Brazilian geopoliticians support the 'frontage theory' (defrontação) of Brazilian geographer Therezinha de Castro, which postulates that each South American country facing the Antarctic should own the sector of Antarctic territory facing its unobstructed coastline. Understandably this appeals also in Uruguay, Peru and Ecuador, which would gain Antarctic territory from its implementation, but is vehemently discredited in Chile and Argentina, who would lose large portions of their present claims.

The Falklands/Malvinas conflict of 1982 represented competition with an outside country for influence and control of the South Atlantic and Antarctic Peninsula. Latin American treaties important in this area are the InterAmerican Treaty of Reciprocal Assistance (the Rio Treaty of 1947) and the (1967) Tlatelolco Treaty, which excluded nuclear weapons from Latin America. As the Rio Treaty covers the South American sector of the South Atlantic as far as the South Pole, Argentina, and Chile can reasonably claim that their treaty responsibilities extend into the Antarctic. So can Brazil argue its responsibility under the Treaty to defend a sizeable portion of the South Atlantic and Antarctica.

Other South Atlantic conflicts considered by GambaStonehouse include (1) The struggle for presence and influence in Antarctica, because the South Atlantic controls access to important sections, especially Antarctic Peninsula: (2) The Argentine-Chile Beagle Channel dispute, in which Argentina strongly resists Chilean penetration into the South Atlantic; Vatican mediation secured uneasy peace in 1985: (3) Law of the Sea disputes among littoral states over new Exclusive Economic Zones. The author argues that international relations may return to a system balancing South Atlantic states (Brazil, Argentina, Uruguay and Paraguay) against South Pacific (Chile, Bolivia, Peru and Ecuador).

The book concludes with a consideration of perceived strategic values of the Western South Atlantic. The sea is beginning to represent a new dimension for South America, of high strategic value. This is a highly recommended review, and a good source-book for comparative research in Latin America policies. The maps will be invaluable to lecturers on Latin American relations and Antarctica. (Julie Schmied, Scott Polar Research Institute, University of Cambridge, Lensfield Road, Cambridge CB2 1ER UK.)

\section{THE FALKLANDS WAR}

THE LITTLE PLATOON: DIPLOMACY AND THE FALKLANDS DISPUTE. Charlton, M. 1989. Oxford, Basil Blackwell. 230 p, hard cover. ISBN 0-631-165649. $£ 14.95$.

For his title Michael Charlton drew on Edmund Burke: for the text of this inspired book he interviewed some 40 people - diplomats, civil servants, ministers of state and humbler politicians, service chiefs of staff, international gurus, UN officials and many others - who were closely involved in events leading up to the Falklands war of 1982 and the conflict itself. His recordings were made in 198586 in the UK, Argentina and USA, while memories and alibis were still fresh, and edited down to eight $B B C$ Radio Three programmes. The book uses more of the material, and to excellent effect; the author asked sensible questions, and the answers, whether sensible or not, make a fascinating study of history and legend in the making.

Charlton discloses remarkable facts - for example that the first-ever visit of a British Foreign Secretary to Latin America was made in 1966 - and a deal of muddled thinking among all who were most closely involved in the dispute from the 1960 s onward. Did responsible Britons really doubt Argentina's determination to acquire the islands, or only their willingness to use force? Did responsible Argentinians really expect Mrs Thatcher and the Brits to allow them a successful invasion? Hindsight favours the Americans, whose predictions appear sharpest throughout, and the common-sense view of the British parliament comes over surprisingly strongly. Britain's shambling foreign policies contrast with the professionalism of its armed forces. Admiral Lord Lewin sums it up on the last page: after the invasion "The chiefs of staff, I think, would have been perfectly within their rights to have said, 'I'm sorry, prime minister, this is the war [the politicians] told us we would not have to fight, and there is nothing we can do to help you'". The author's conclusion that : 'Britain fought a war ... for islands it had spent the better part of twenty years suggesting it did not want' is inescapable. So is his dictum that '... political leaders who avoid the difficult choices face harder ones in the end'. This is an excellent book, strongly recommended 
for leisure reading as well as for serious study. (Bernard Stonehouse, Scott Polar Research Institute, University of Cambridge, Lensfield Road, Cambridge CB2 1ER UK.)

\section{BIRDS OF ALASKA}

BIRDS OF THE SEWARD PENINSULA, ALASKA. Kessel, Brina. Fairbanks, University of Alaska Press. 330 $\mathrm{p}$, illustrated, hard cover. ISBN 0-912006-29-3. US\$36.95.

Subtitled 'their biogeography, seasonality and natural history', this is far more than a catalogue of Alaskan birds and their ways. Written by one of the state's leading ornithologists (for whom it surely represents a life's work), it includes a geographical and climatic rundown of the Seward peninsula region, comprehensive descriptions of avian habitats from uplands to shoreline, tables of species abundance in different habitats, zoogeographic affinities of breeding birds and casual visitors, and seasonal patterns of avian activities. The bulk of the book is a comprehensive account of each of 215 species that have been recorded on the peninsula, together with an extensive bibliography and index. Illustrated with maps, photographs and drawings, this will clearly be the definitive book on the ornithology of western Alaska for some years. Available direct from the Press, University of Alaska Fairbanks, Fairbanks AK 99775-1580 USA. (Bernard Stonehouse, Scott Polar Research Institute, University of Cambridge, Lensfield Road, Cambridge CB2 1ER UK.)

\section{POLAR RESOURCE MANAGEMENT}

INTERNATIONAL RESOURCE MANAGEMENT: THE ROLE OF SCIENCE AND POLITICS. Andresen, S. and Østreng, W., 1989. London, Belhaven Press. 301 $\mathrm{p}$, illustrated, hard cover. ISBN 1-85293-097-7. £30.00.

Arising from a 1988 conference to celebrate the thirtieth birthday of the Norwegian Fridtjof Nansen Institute, this assembly of 14 papers is by authors of several nationalities; not surprisingly many are Scandinavian and, though world problems are covered, there are strong Arctic overtones.

Exploring interfaces between international politics and the science and technology of resource management, the papers cover a range of examples from trans-boundary pollution to economics of whale and fish stocks. Four sections (Science and International Regimes; Science, Environment and Development; Science and International Pollution; Science and Living Resources) muster many ideas useful for polar scientists and administrators. A chapter on 'Polar science and politics' (Østreng) discusses the role of science as currency in Antarctic politics and its possible role in the future of the Arctic; 'Global environmental monitoring and informations systems - an operational perspective' (Christoffersen) and 'Science and politics in the protection of the ozone layer' (Bakken) have particular polar relevance, and several other chapters deal with or touch on polar issues.

The book includes a listing of relevant international organizations, a bibliography and good index. This is a stimulating symposium for students of ecology, politics, management and international affairs. (Bernard Stonehouse, Scout Polar Research Institute, University of Cambridge, Lensfield Road, Cambridge CB2 IER UK.)

\section{BRIEF REVIEWS}

ARCTICCIRCLE: ROVANIEMI-NUORGAM. Finnish National Committee of the European Cultural Foundation. 1988. Helsinki, FNCECF. 192 p, illustrated, soft cover. ISBN 951-8932-00-X.

ARCTIC CIRCLE II: ROVANIEMI-KILPISJÄRVI.. Finnish National Committee of the European Cultural Foundation. 1989. Helsinki, FNCECF. 192 p, illustrated, soft cover. ISBN 951-8932-01-8.

Two pocket-sized guides to the Finnish northlands, covering respectively the eastern and western halves. Their purpose is '... to create a cultural route to Lapland, along which the road opens to nature and the history of habitation in a new way.' Intelligent, beautifully produced with colour photographs and maps, they are comprehensive travellers' guides covering geography, geology, social and natural history, architecture, ethnology, agriculture, reindeer-herding and Saami culture - indispensable in the field and a pleasure for armchair reading. Strongly recommended for anyone who wants to know anything about the northern half of Finland. Both available in English. May be ordered by mail from the Finnish National Committee of the European Cultural Foundation, Kaisaniemenkatu 2 b III, Helsinki, Finland.

THE ROLE OF ANTARCTICA IN GLOBAL CHANGE. SCAR Steering Committee for the IGBP. 1989. Cambridge, ICSU Press/SCAR. 28 p, illustrated, soft cover. ISBN 0-930-35718-3. £6.00.

Subtitled 'Scientific priorities for the International Geosphere-Biosphere Programme (IGBP), this booklet sets out ways in which the SCAR-IGBP Steering Committee believes that Antarctic science can contribute to the IGBP, identifying areas in which Antarctic programmes are especially relevant to Global Change projects. A useful survey of currrent Antarctic environmental studies, obtainable from SCAR, Scott Polar Research Institute, Lensfield Road, Cambridge CB2 1ER UK.

CIRCUMPOLAR HEALTH 87: PROCEEDINGS OF THE 7TH INTERNATIONAL CONGRESS ON CIRCUMPOLAR HEALTH. Linderholm, $\mathrm{H}$. and others (editors). 1988. Umea,, Nordic Council for Arctic Medical Research. 734 p, illustrated, hard cover. ISBN 95199932-2-3. (Arctic Medical Research 47: Supplement 1.)

Every few years the Intemational Congresses on Circumpolar Health meet to discuss every conceivable topic of health, health care and disease, notably in the Arctic but also in the Antarctic. The terms 'circumpolar' and 'health' are liberally interpreted, each successive Congress covering wider fields than the last. This volume reports on the June 1988 meeting in Umeå, Sweden. It lists over 180 research papers and reviews under headings that include Circumpolar environment and human adaptation; Health care education, planning and delivery; and Circumpolar 